УДК 316.344.24

Олійник, О. (2020). Значення другого (магістерського) рівня вищої освіти для студентів і роботодавців у сфері інформаційних технологій і соціології. Соціологічні студіï, 1 (16), 22-28.

DOI: https://doi.org/10.29038/2306-3971-2020-01-22-28

\title{
Значення другого (магістерського) рівня вищої освіти для студентів і роботодавців у сфері інформаційних технологій і соціології
}

\begin{abstract}
Оксана Олійник -
кандидат сочіологічних наук, доиент кафедри

методології та методів сочьілогічних досліджень, Київський національний університет імені Тараса Шевченка, Україна.
\end{abstract}

\author{
Oksana Oliinyk - \\ PhD in Sociology, Associate \\ Professor, Department of \\ Methodology and Methods of \\ Sociological Research, \\ Taras Shevchenko National \\ University of Kyiv, Ukraine. \\ Email: o_oliinyk@ukr.net \\ ORCID: \\ https://orcid.org/0000-0003- \\ 0568-7940
}

DOI: https://doi.org/10.29038/

2306-3971-2020-01-22-28

Reseived: March, 2020

$1^{\text {st }}$ Revision: March, 2020

Accepted: April, 2020
Одна 3 проблем сьогодення - відставання освіти від розвитку запитів суспільства на фахівців. Цю проблему досліджують із позицій двох стратегій: кількісна дає уявлення про сегментацію ринку праці, позиції на ринку праці осіб із вищою освітою та про кількісні оцінки якості освітніх послуг, настанови учасників освітнього процесу й роботодавців щодо освітніх програм і рівнів освіти тощо; якісна дає змогу зрозуміти причини та механізми формування цих оцінок.

Мета статті - дослідити ставлення роботодавців (на прикладі IT сфери й соціології та маркетингу) до якості навчання в закладах вищої освіти й важливість для них наявності в потенційних працівників освітнього ступеня бакалавра чи магістра, а також ставлення студентів до здобуття освітнього ступеня «магістр» у зазначених сферах, мотиви вступу до магістратури. Це дасть змогу осмислити значення другого (магістерського) рівня вищої освіти, порівняно 3 першим (бакалаврським) у сферах соціології, маркетингу, IT.

У статті проаналізовано серію глибинних інтерв'ю студентів частини факультетів КНУ імені Тараса Шевченка й роботодавців у відповідних сферах, з'ясовано їхні настанови щодо отримання випускниками бакалаврату другого (магістерського) рівня вищої освіти.

Роботодавці здебільшого оцінюють рівень підготовки фахівців як достатній. Для них відмінність між освітніми ступенями «магістр» i «бакалавр», здобутими випускниками та зазначеними в дипломах про вищу освіту, не має суттєвого значення в процесі найму на роботу працівників зазначених сфер. Називаючи вимоги до найманих працівників, окрім набору відповідних Hard Skills, великого значення вони надають базовим навичкам спілкування, знанню англійської й української мов, відповідальності, іншим Soft Skills.

Студенти ж більшого значення надають саме вузькопрофесійним прикладним дисциплінам і відповідним навичкам. При цьому їхнє бажання вступати до магістратури пов'язані переважно або з потребою вдосконалити свої професійні навички, або з бажанням отримати другу вищу освіту за іншим спорідненим фахом.

Ключові слова: вища освіта, вимоги до випускників 3ВО, роботодавці, Hard Skills, Soft Skills, освітній рівень.

Oliinyk Oksana. The Importance of the Second (Master's) Level of Higher Education for Students and Employers in the Field of Information Technology and Sociology. One of today's problems is the lag of education from the development of society's demands for specialists. This problem is studied from the standpoint of two strategies - quantitative gives an idea of the shortage and oversaturation of the market by certain groups of professionals, quantitative assessments of the quality of educational services, the relationship of educational programs and levels of education etc. Qualitative help to understand the reasons and mechanisms of formation of these estimations.

The purpose of the article is to analyze the attitude of employers (on the example of IT, sociology and marketing) to the quality of education in universities and the importance of potential employees with a bachelor's or master's degree, as well as students' attitude to master's degree in these areas and motives to reach the master's degree. It will allow us to understand the importance of the master's degree to the bachelor's degree in the fields of sociology, marketing or IT.

The article analyzes a set of focused interviews of students of the faculties of Taras Shevchenko National University of Kyiv and employers in appropriate fields, clarifies employers`instructions for graduates of the master's degree. 
Employers generally rate the level of employees` training as sufficient. The difference between the master's and bachelor's degrees of employees for them is not significant in the process of hiring employees in these areas. When giving the requirements for employees, in addition to a set of appropriate Hard Skills, basic communication skills, knowledge of English and Ukrainian, responsibility, and other Soft Skills are in great importance.

Students attach more importance to narrow disciplines. At the same time, their desire to enter the master's program is mainly related either to the need to improve their professional skills, or to the desire to obtain a second higher education in another related specialty. level.

Key words: higher education, requirements for university graduates, employers, Hard Skills, Soft Skills, educational

Олейник Оксана. Значение второго (магистерского) уровня высшего образования для студентов и работодателей в области информационных технологий и социологии. Одна из проблем современности отставание образования от развития запросов общества к качеству подготовки специалистов. Система высшего образования предлагает сегодня получение двух уровней образования - первого (бакалаврского) и второго (магистерского) уровней.

Цель статьи - исследовать отношение работодателей (на примере сферы информационных технологий, а также социологии и маркетинга) к качеству обучения в учреждениях высшего образования и значение для них наличия у потенциальных работников первого (бакалаврского) и второго (магистерского) уровней образования в указанных сферах, мотивы поступления в магистратуру.

В статье анализируется серия глубинных интервью студентов части факультетов КНУ имени Тараса Шевченко и работодателей в сферах социологии, маркетинга, ИТ; выясняются их установки к получению выпускниками бакалавриата второго (магистерского) уровня высшего образования.

Работодатели в целом оценивают уровень подготовки специалистов как достаточный. Для них различие между образовательными уровнями «магистр» и «бакалавр», полученными выпускниками и указанными в дипломах о высшем образовании, не имеет существенного значения в процессе найма на работу специалистов указанных сфер. Основные их требования - наличие у соискателя соответствующих Hard Skills, базовых навыков общения, знания английского и украинского языков, ответственности, других Soft Skills.

Студенты же большее значение придают именно узкопрофильным прикладным дисциплинам и соответствующим навыкам. При этом их желание поступать в магистратуру связаны преимущественно или с необходимостью усовершенствовать свои профессиональные навыки, или с желанием получить второе высшее образование по другой родственной специальности.

Ключевые слова: высшее образование, требования к выпускникам вузов, работодатели, Hard Skills, Soft Skills, образовательный уровень.

Постановка наукової проблеми та її значення. Ви́ща осві́та, яка характеризується рівнем знань, умінь і навичок, що набуваються в закладах вищої освіти на базі повної загальної середньої освіти, необхідна фахівцям вищої кваліфікації в різних галузях. Вища освіта, яка здобувається в освітньому закладі, унаслідок послідовного, системного та цілеспрямованого процесу засвоєння змісту навчання грунтується на повній загальній середній освіті й завершується здобуттям певної кваліфікації за підсумками державної атестації.

Але, попри це, ще й досі багато студентів мають великі сумніви щодо навчання в університеті із погляду на практичну цінність та результати навчання. Наскільки затребуваною для студентів $\epsilon$ магістратура? Чи існують реальні преференції диплому магістра перед дипломом бакалавра в уявленнях роботодавців та чи вважають вони рівень навчання достатнім для працевлаштування студента загалом? Наскільки цінною є вища освіта і які навички - Hard Skills чи Soft Skills важливіші для роботодавців?

Емпірична база дослідження. Спробуємо відповісти на ці та інші питання, грунтуючись на кількох серіях глибинних інтерв'ю, проведених у межах різних проєктів ${ }^{1}$ iз роботодавцями у сферах соціології й інформаційних технологій (IT), випускниками бакалаврату факультетів кібернетики, соціології та філософського факультету (спеціальність «Політологія»), які збирала авторка впродовж 2018-2020 р. Серія із 27 фокусованих глибинних інтерв’ю включає два інтерв’ю з роботодавцями у

\footnotetext{
${ }^{1}$ Авторка статті в процесі викладання різних дисциплін на трьох факультетах керувала дослідницькими проєктами студентів, а також сама проводила інтерв’ю з ними та роботодавцями у сферах соціології й маркетингу, а також інших (банківській, виробничій, IT) - під час конференцій Uni-Biz bridge, створених для взаємодії студентства, викладачів і роботодавців, у яких дослідниця брала участь.
} 
сфері соціології, два - у сфері маркетингу, 10 - IT (ці інтерв’ю проведено студентами 1 року магістратури спеціальності «Бізнес і інформатика» факультету кібернетики в межах навчального проєкту з дисципліни «Методи соціальних досліджень» iз 1 по 30 квітня 2019 р.), шість інтерв’ю із представниками банківської сфери, аудиту, торгівлі, виробництва, HR, зроблені авторкою під час конференцій Uni-Biz bridge у квітні та у вересні 2019 р., 11 - зі студентами-випускниками бакалаврату (два - факультет кібернетики і комп’ютерних наук, спеціальність «Бізнес і інформатика», три - філософський факультет, спеціальність «Політологія», шість - факультет соціології, освітня програма «Соціологія»).

Аналіз останніх досліджень та публікацій. На сьогодні тема якості вищої освіти дуже актуальна як у науковій літературі, так і в тематиці соціологічних досліджень багатьох організацій.

Значний внесок у розвиток соціологічного дослідження освітніх проблем, у т. ч. й проблем вищої освіти, робить Українська асоціація дослідників освіти (UERA) ${ }^{1}$, зокрема проєкт «Підтримка реформування вищої освіти в Україні» (Enhancing Higher Education Reform in Ukraine), мета якого сприяння реформуванню вищої освіти в Україні шляхом підвищення рівня професіоналізму університетів у навчальній і науковій діяльності, залучення викладачів до обміну академічним досвідом, проведення емпіричних досліджень в освіті (Enhancing Higher Education..., 2017).

Проєкт «Рейтинг українських вищих навчальних закладів за ступенем задоволеності освітою “Компас"», здійснюваний Київським міжнародним інститутом соціології, проводився у 20082013 рр. із застосуванням методів особистого й телефонного інтерв’ю, опитування за допомогою електронної пошти та онлайн-опитування. ${ }^{2}$ Таку сукупність методів обрано 3 огляду на те, щоб досягнути якомога більше випускників різних закладів вищої освіти та важкодосяжних респондентів (роботодавців, експертів тощо). Аби більш комплексно оцінити якість освіти, котру надають українські заклади вищої освіти, учасникам дослідження (випускникам і представникам компаній-роботодавців) у межах проєкту ставили додаткові запитання стосовно різних аспектів діяльності 3ВО, досвіду працевлаштування, професійних навичок і компетенцій випускників. Останні деталізовані дані, які доступні, засвідчили, що роботодавці неоднозначно оцінюють зміни як підготовку сучасних випускників українських 3ВО: серед недоліків експерти-роботодавці відзначали певне падіння рівня загальної грамотності (недостатне володіння мовами, зниження рівня ерудиції, брак знань із загальних дисциплін), недостатність таких практично-професійних навичок, як уміння вирішувати проблемні ситуації й навички роботи 3 клієнтами. (Випускники українських ВНЗ..., 2012). Ця публікація містить багато цікавих результатів, які можуть допомогти 3ВО покращити якість освітніх послуг. Утім, серед запитань до роботодавців відсутні запитання про важливість для них набутого випускником ЗВО освітнього ступеня як чинника його успішного працевлаштування.

Тематика дослідження інституту вищої освіти не оминає такі відомі компанії, як КМIC, Центр Разумкова, GfK Ukraine, CEDOS, Український інститут соціальних досліджень імені О. Яременка й ін.

Регулярно проводять моніторинг якості надання освітніх послуг і самі ЗВО. Факультетом соціології Київського національного університету імені Тараса Шевченка (КНУТШ) неодноразово проводились опитування думки роботодавців та випускників, студентів (про їхні майбутні плани), а також викладачів (зокрема Критерії вибору..., 2013; Працевлаштування НЕ за фахом, 2013; Діяльність після..., 2013). Проте питання ставлення здобувачів вищої освіти до отримання ступеня бакалавра чи магістра фактично не порушувалося.

Мета статті - дослідити ставлення роботодавців (на прикладі IT-сфери, соціології й маркетингу) до рівня навчання у вищих закладах освіти та важливість для них наявності в потенційних працівників освітнього рівня бакалавра чи магістра, а також ставлення студентів до здобуття освітнього рівня «магістр» у зазначених сферах, мотиви вступу до магістратури. Це дасть змогу осмислити значення другого (магістерського) рівня вищої освіти, порівняно 3 першим (бакалаврським), у сферах соціології, маркетингу, IT.

Виклад основного матеріалу й обгрунтування результатів дослідження. Останні роки освітяни помічають тенденцію до зниження рівня зацікавленості випускників бакалаврату продовжу-

\footnotetext{
${ }^{1}$ Українська асоціація дослідників освіти (UERA): http://www.uera.org.ua/?page=1

2 Про проект «Компас»: http://www.yourcompass.org
} 
вати навчання за фахом у магістратурі. Ще більш помітно знижується інтерес випускників до аспірантури. Аби з'ясувати, у чому причини зниження інтересу студентів до магістратури, проаналізуємо серію інтерв'ю із самими випускниками бакалаврату, а також із роботодавцями, які формують набір вимог до найманих працівників. Для аналізу візьмемо представників обох груп опитаних (роботодавців і студентів) двох різних сфер діяльності, а саме соціологів та політологів (серед останніх - лише студенти) як представників сфери соціальних наук, а також відповідних представників сфери комп'ютерних наук й IT. Спробуємо визначити спільне та відмінне, а також знайти аргументи на користь магістерської освіти й причини незацікавленості нею.

Думка роботодавців. Роботодавці сфери IT здебільшого негативно або нейтрально оцінюють зміни в якості підготовки сучасних випускників українських ЗВО: частина опитаних указали на те, що за останні п'ять років якість підготовки випускників в українських ЗВО погіршилася, ще частина - що не змінилася й двоє роботодавців із 10 відзначили покращення якості підготовки молодих спеціалістів упродовж останніх років.

Серед загальних тенденцій, які б могли описати особливості та характеристики сучасного випускника, респонденти під час експертних інтерв'ю говорили про падіння за останні роки середнього рівня знань, маючи на увазі не лише знання за фахом, але й недостатній рівень базової грамотності: недостатній рівень володіння усною та писемною українською або російською мовами, загальну ерудицію, знання в галузі загальноосвітніх дисциплін тощо.

Найбільш важливими якостями працівників, на думку роботодавців, як у сфері IT, так і в соціології, маркетингу, банківській справі, $є$ практично-професійні навички, але не менш важливими $€$ й уміння вирішувати проблемні ситуації, дисциплінованість та самоорганізація, уміння працювати в колективі, тобто Soft Skills. I саме цих навичок, за оцінками роботодавців, найчастіше бракує молодим спеціалістам. Великі підприємства більш гостро відчувають недостатню компетентність таких фахівців, адже, зазвичай, чим більше підприємство, тим вищий і жорсткіший рівень вимог, а отже, тим відчутніша нестача тих чи інших навичок у співробітників. Деякі роботодавці у своїх інтерв’ю говорили й таке: «У крайньому разі оволодіння Hard Skills - лише справа часу й ми можемо навчити молодь вже на робочому місиі, хоча, звісно, для иього потрібні час і ресурси, насамперед людські, а тому ие просто невигідно компанії. Проте навчити відповідальності, комунікативної етики тощо ми не зможемо».

Проблемою так само залишається розрив між теоретичними знаннями, які дає ЗВО, та їх практичним застосуванням у реальних умовах.

Експерти у сфері управління персоналом (директори з персоналу провідних компаній і фахівці HR) підтверджують наявність розриву в тих навичках, які отримує випускник 3BО, і тими навичками, котрі треба мати вже працівнику компанії. Утім, більшість роботодавців вважають, що вища освіта $\epsilon$ необхідною умовою працевлаштування в їхній компанії: про це сказали сім із 10 роботодавців сфери, усі опитані соціологи та маркетологи, а також в умовах конференції на запитання до дев’яти присутніх роботодавців таку відповідь дали абсолютно всі.

Проте власний досвід експертів, а тим більше експертів різних сфер, різниться, а відтак ми навіть не намагатимемося в цій статті формувати єдиний стандарт вимог для наймання працівників. Проте можна назвати ті, що названі роботодавцями з різних сфер як певний «мінімальний універсальний набір» вимог.

Роботодавці у сфері соціології й маркетингу, як підтверджують і попередні дослідження, проведені факультетом соціології КНУТШ (Критерії вибору..., 2013), називають володіння комп'ютером загалом та сучасними програмами обробки даних зокрема, особисті якості, фахові знання й навички, знання іноземних мов, репутацію ЗВО. Так само переплітаються у вимогах інших фахівців особисті та професійні навички (дисциплінованість, знання української мови не менш важливі для IT-шників, ніж навички програмування).

В умовах постійного збільшення кількості студентів денної форми навчання, які поєднують навчання й роботу (із кожним курсом їх чисельність зростає ${ }^{1}$ ), як засвідчують отримані нами

${ }^{1}$ Уже у 2015 р., за результатами кількісного дослідження, їх частка становила 65 \%, простежено тенденцію до збільшення. 
результати (Олійник, Сидоров, 2015, с. 163), та прагнення студентів якомога раніше здобувати професійний досвід і матеріальну незалежність, у них природно постає питання: чи є потреба вступати до магістратури, якщо після бакалаврату вони вже мають вищу освіту, роботу та перелік необхідних Hard Skills. Ми та студенти факультету кібернетики (магістри першого року навчання, спеціальності «Бізнес і інформатика») ставили це запитання роботодавцям (відповідно, у сферах соціології, маркетингу й IT).

Як засвідчили результати інтерв'ю з роботодавцями сфери IT стосовно важливості отримання повної вищої освіти, здобуття освітнього ступеня «бакалавр» і «магістр», відповіді відчутно різняться: більшість респондентів зазначили, що важливим є критерій отримання ступеня бакалавра для вищої освіти, ступінь магістра не має принципового значення; ще частина роботодавців відзначала, що незакінчена вища освіта на базі двох курсів бакалаврату є достатньою для працевлаштування; один зазначив, що наявність магістратури - це важливий критерій для працевлаштування потенційного працівника.

«Получение студентом аккредитаџии бакалавра есть очень важным для меня, ибо это показывает, что человек смог пройти университетскую узкоспецеализированную программу обучения, что свидетельствует о том, что человек способен к обучению на соответствующем уровне, что крайне необходимо для нового специиалиста в команде, и я могу быть спокоен, что всю базу IT ему было предоставлено в университете, и это огромный плюс по сравнею с людыми, которые не окончили бакалаврат и занимались самообучением».

"Для меня факт наличия степени магистра у новоиспеченных сотрудников является важныл, ибо это означает что он прошел полноценные 6 лет подготовки к тому, чтобы стать хорошим специалистом; показывает, что он может доводить дело до кония, не боится трудностей и не бросает все на полпути, да и к тому же возраст сотрудника в таком случае стартует от 2223 лет, что способствует большей сосредоточенности специалиста на работе».

Подібні відповіді отримано й в інтерв'ю з роботодавцями випускників-соціологів:

"Для мене взагалі не важливий рівень вищої освіти працівника. Головне, аби він володів навичками обробки даних, умів якісно аналізувати інформацію в різних пакетах».

«Если человек окончил магистратуру, прослушал дополнительные спецкурсы в университете, значит, он лучше владеет профессиональньми навыками».

Також отримані результати інтерв'ю засвідчили, що роботодавці охоче наймають студентів, спираючись на їхній малий досвід. Аргументують вони це тим, що роботодавцям «є легшим та більш ефективнішим поєднати команду зі спеціалістом, у якого є недостатньо досвіду, ніж зі студентом чи пересічним потенційним кадром, щзо має багаторічну практику на різних проєктах, бо так він легше вливається в команду, засвоює корпоративні норми, адже йому немає з чим порівнювати й оичнювати».

Роботодавці з банківської сфери та сфери IT зазначили, що від університетів вони очікують лише міцних базових знань (Hard Skills), решту навичок, а саме: роботи зі спеціальним програмним забезпеченням, ознайомлення 3 принципами діяльності організації тощо - вони й так здебільшого надають самотужки. Деякі організації, як-от Deloitte (фінансовий аутсорсинг, бухгалтерський облік) задіяні в навчанні студентів разом із КНЕУ, і це відображено в освітній програмі та навчальних програмах дисциплін.

Отже, аргументами роботодавців на користь магістратури є:

- вищий рівень підготовки випускника, порівняно з бакалавратом;

- триваліший термін навчання як показник цілеспрямованості найманого працівника.

Аргументів «проти» явно не звучало, утім, не менше ніж половина опитаних роботодавців заявили, що наявність освітнього рівня магістра не має для них принципового значення; головні вимоги - володіння базовими професійними навичками, не менш важливими є загальний рівень грамотності (комунікативної, комп’ютерної, знання мов тощо) й особисті риси найманого працівника.

Думка студентів. Нами особисто проведено глибинні інтерв'ю зі студентами, які закінчують бакалаврат за спеціальностями «Соціологія» та «Політологія», а також магістрами першого року навчання факультету кібернетики. Ключовим було питання щодо намірів стосовно магістратури. Відповіді видалися дуже різноманітними й цікавими, як і аргументи «за» та «проти» магістратури. 
Аргументи «за»:

- бажання отримати другу (іншу за напрямом, фахом) вищу освіту;

- бажання поглибити знання, удосконалити професійні навички;

- бажання подовжити собі студентство (зокрема в умовах, коли бажану роботу не знайдено);

- бажання послухати інших викладачів в іншому університеті, продовжуючи навчання за тією самою спеціальністю:

«У мене вже є вища освіта за фахом “Політологія”, я хочу отримати ще одну, іншу, пов 'язану з першою, але більш прикладну спеціальність. Ну і дипломів у мене буде теж два (сміється)».

"Я зможу прослухати ще аналіз в $R$, аналіз нечислових даних, яких мені забракло на бакалавраті».

«Ну, якщо я не зможу на той час налаштувати свій бізнес і в мене буде бажання подовжити собі студентство, побути ще два роки в цій тусовиі, то вступатиму, звісно».

«Я вже чотири роки слухала ичих викладачів. Що нового вони зможуть мені розповісти ще наступні два? Краще я послухаю когось іншого».

Аргументи «проти»:

- відчуття достатності освітнього ступеня «бакалавр»;

- наявність роботи, яка задовольняє, а магістратура вимагатиме виділяти на навчання час;

- утома від навчання:

«Я вже маю вищу освіту, яка дає мені змогу прачювати за фахом. Я не бачу необхідності вчитися ще два роки. Викладати я не збираюся, а для моєї роботи здобутих знань иілком достатньо».

«Я працюю за спеиіальністю з третього курсу. Начальство мені два роки робить поблажки, відпускає на навчання. Ще два роки в такому режимі - для чого?».

"Думаю, щзо знань і навичок, яких нас навчали чотири роки, иілком достатньо. Якщя треба буде по роботі щось опанувати, буду підучуватися, може, піду на курси. Але, чесно кажучи, універ мені вже набрид. Я втомився».

Висновки та перспективи подальших досліджень. Проведений аналіз дає підставу зрозуміти позиції основних споживачів послуг вищої професійної освіти - роботодавців і студентів, прояснює не лише їхні оцінки сучасної вищої освіти (на прикладі соціології, IT), але й визначає їх очікування від інституту вищої освіти. Як засвідчив аналіз, опитані роботодавці (сфери IT, соціології, маркетингу та ін.) не надають великого значення рівню вищої освіти, зазначеному в дипломі претендента на роботу в його організації. Для студентів же магістратура - це шанс удосконалити свої професійні знання й навички, можливість отримати другу вищу освіту за іншою спеціальністю або подовжити період навчання. Проте отримана інформація ставить нові запитання й змушує замислитися над іншими питаннями, як-от: 1) наскільки затребуваними є магістерські програми для роботодавців і студентів, що вони очікують від них; 2) як організаційно поєднати навчання на магістратурі з роботою студентів; 3) наскільки цінними $є$ Hard Skills, які дає університет, порівняно iз Soft Skills, та, відповідно, як змінюються цінності професіоналізму й компетентності в суспільстві?

\section{Джерела та література}

1. Enhancing Higher Education Reform in Ukraine (Report) (2017). Retrieved May 31, 2020 from https://drive.google.com/file/d/1kr_HPLR_Dpgmoh_45GaTHaAQhXLmZTBz/view

2. Випускники українських ВНЗ очима роботодавиів: результати дослідження (2012). Отримано 31 травня 2020 p. 3 https://www.yourcompass.org/docs/Employees\%20on\%20University_Graduates.pdf

3. Критерії вибору роботодавием працівника (2013). Отримано 31 травня 2020 p. 3 https://www.soc.univ.kiev.ua/uk/nauka/kryteriyi-vyboru-robotodavcem-pracivnyka

4. Прачевлаштування HE за фахом (2013). Отримано 31 травня 2020 p. 3 https://www.soc.univ.kiev.ua/uk/nauka/pracevlashtuvannya-ne-za-fahom-0

5. Діяльність після закінчення навчання (2013). Отримано 31 травня 2020 p. 3 https://www.soc.univ.kiev.ua/uk/nauka/diyalnist-pislya-zakinchennya-navchannya

6. Олійник, О., Сидоров, М. (2015). Проблема якості вищої освіти в умовах трудової зайнятості студентів. Молодіжна політика: проблеми та перспективи: зб. наук. пращь, 6, 161-167.

\section{References}

1. Enhancing Higher Education Reform in Ukraine (Report) (2017). Retrieved May 31, 2020 from https://drive.google.com/file/d/1kr_HPLR_Dpgmoh_45GaTHaAQhXLmZTBz/view 
2. Graduates of Ukrainian universities through the eyes of employers: the results of the study (2012). Retrieved May 31, 2020 from https://www.yourcompass.org/docs/Employees\%20on\%20University_Graduates.pdf

3. Criteria for selecting an employee by the employer (2013). Retrieved May 31, 2020 from https://www.soc.univ.kiev.ua/en/nauka/criteria-selecting-employee-employer

4. Jobs in other areas (2013). Retrieved May 31, 2020 from https://www.soc.univ.kiev.ua/en/nauka/jobs-otherareas

5. Activities after graduation (2013). Retrieved May 31, 2020 from /https://sociology.knu.ua/en/nauka/activitiesafter-graduation

6. Oliinyk, O., Sydorov, M. (2015). The problem of quality of higher education in the conditions of employment of students. Youth policy: problems and prospects, 6, 161-167. 